\title{
DEPLETION OF SOMATOSTATIN-LIKE IMMUNOREACTIVITY IN THE RAT CENTRAL NERVOUS SYSTEM BY CYSTEAMINE ${ }^{1}$
}

\author{
STEPHEN M. SAGAR, ${ }^{2}$ DONALD LANDRY, ${ }^{3}$ WILLIAM J. MILLARD, THOMAS M. BADGER, ${ }^{*}$ \\ MICHAEL A. ARNOLD, AND JOSEPH B. MARTIN \\ Department of Neurology and ${ }^{*}$ Department of Gynecology, Massachusetts General Hospital, Boston, Massachusetts 02114
}

Received July 31, 1981; Accepted October 8, 1981

\begin{abstract}
Selective neurotoxins have been of value in providing a means for specifically interfering with the actions of endogenous neurotransmitter candidates. Others have shown cysteamine (CSH) to deplete the gastrointestinal tract and hypothalamus of rats of immunoreactive somatostatin, suggesting a toxic action of that compound directed against somatostatin-containing cells. The present study further defines the actions of cysteamine on somatostatin in the central nervous system (CNS). Cysteamine hydrochloride administered subcutaneously results in a depletion of somatostatin-like immunoreactivity (SLI) in the retina, brain, and cervical spinal cord of rats. The effect is demonstrable at doses of $30 \mathrm{mg} / \mathrm{kg}$ of body weight and above, occurs within 2 to $4 \mathrm{hr}$ of a single injection of the drug, and is largely reversible within 1 week. The mean depletion of SLI observed within the CNS varies from $38 \%$ in cerebral cortex to $65 \%$ in cervical spinal cord $24 \mathrm{hr}$ following administration of $\mathrm{CSH}, 300 \mathrm{mg} / \mathrm{kg}$ of body weight, s.c. By gel permeation chromatography, all molecular weight forms of SLI are affected, with the largest reductions in those forms that co-chromatograph with synthetic somatostatin-14 and somatostatin-28. These results indicate that CSH has a generalized, rapid, and largely reversible effect in depleting SLI from the rat CNS.
\end{abstract}

Cysteamine (2-mercaptoethylamine, $\mathrm{CSH})$ is a thiol reagent whose biological activities have been investigated extensively. Experimentally, it has been used as a radioprotective agent (Bacq, 1965) and as an ulcerogen in rats (Selye and Szabo, 1973). Clinically, it has been used in the treatment of acetaminophen (paracetamol, Tylenol) poisoning (Prescott et al., 1976) and, more recently, in the treatment of cystinosis (Yudkoff et al., 1981).

Szabo and Reichlin (1981), in the course of studying the ulcerogenic properties of $\mathrm{CSH}$, found that the oral

\footnotetext{
' This work was supported by funds from the Foundation for Nutritional Advancement and by National Institutes of Health Grants AM26252 and NS16367 to J. B. M. and Grant HD14586 to T. M. B. S. M. S., W. J. M., and M. A. A. were postdoctoral fellows supported by the National Eye Institute, the National Institute of Arthritis, Metabolism, and Digestive Diseases, and the National Science Foundation, respectively. The technical assistance of Linda Lorenz and the secretarial assistance of Katherine Sullivan are gratefully acknowledged. This work was presented in part at the 33rd Annual Meeting of the American Academy of Neurology and has been published in abstract form (Sagar et al., 1981).

${ }^{2}$ To whom correspondence should be addressed at Neurology Research Laboratory, Massachusetts General Hospital, Boston, MA 02114.

${ }^{3}$ Present address: College of Physicians and Surgeons, Columbia University, New York, NY 10032.
}

administration of CSH produces an acute, partial depletion of somatostatin-like immunoreactivity ${ }^{4}$ (SLI) in the gastrointestinal tract and hypothalamus of rats. This effect is potentially of great interest in neuropeptide research. In the absence of a specific pharmacologic receptor antagonist for somatostatin, there is no generally useful means available for selectively blocking the action of endogenous somatostatin in the central nervous system (CNS). If CSH proves specific, if it is effective throughout the CNS, and if the depletion of somatostatin is sufficient to be of physiological consequence, then $\mathrm{CSH}$ could provide such a method. Moreover, elucidation of its mechanism of action may provide clues to the biochemistry of the synthesis, release, or degradation of the somatostatin family of peptides.

This study was designed to define the dose-response relationship for a single parenteral dose of $\mathrm{CSH}$, to de-

\footnotetext{
${ }^{4}$ The nomenclature used in this paper for the somatostatin-related peptides is as follows: somatostatin-14 and somatostatin-28 denote peptides of known amino acid sequence and chemical structure (Burgus et al., 1973; Pradayrol et al., 1980). Somatostatin-like immunoreactivity (SLI) refers to a measurement made by radioimmunoassay, related to nanograms of somatostatin-14 used in the standard curve. Immunoreactive somatostatin, or somatostatin, refers to the entire family of peptides present in tissue extracts which cross-react immunologically with somatostatin-14.
} 
termine if the effect of systemically administered CSH occurs throughout the CNS or is limited to the hypothalamus, to define the time course of the action of $\mathrm{CSH}$ in the brain, and to define, by gel permeation chromatography, the species of immunoreactive somatostatin affected.

\section{Materials and Methods}

Animals. Adult, male Long-Evans hooded rats (Charles River) weighing 275 to $375 \mathrm{gm}$ were housed in colony cages with free access to chow and water. Lights were on between 6 A.M. and 6 P.M.; the temperature was maintained at $22^{\circ} \mathrm{C}$ and the humidity was kept at $30 \%$. Drug injections were made between 9 A.M. and 12 noon.

Chemicals. Cysteamine $\mathrm{HCl}$ was obtained from Sigma Chemical Co. (St. Louis) and was stored desiccated at $4^{\circ} \mathrm{C}$. Solutions were made in distilled water on the day of injection and were neutralized with $1 \mathrm{~N} \mathrm{NaOH}$. Doses are expressed as milligrams of the $\mathrm{HCl}$ salt per $\mathrm{kg}$ of body weight. Synthetic somatostatin-14 was purchased from Beckman (Palo Alto, CA); synthetic somatostatin-28 was generously provided by Drs. P. Brazeau and N. C. Ling of the Salk Institute, San Diego, CA. Horse heart cytochrome $c$ (Type III) and bovine serum albumin (RIA grade) were purchased from Sigma. Other chemicals used were of reagent grade or better.

Tissue extraction. Animals were killed by decapitation and their brains and eyes were removed promptly and placed on ice. Regional dissection of the brain was performed according to the landmarks of Glowinski and Iversen (1966). Unless otherwise noted, cerebral cortex refers to the entire region as defined by those authors. Parietal cortex refers to a subregion of the cerebral cortex dissected by making coronal sections of the brain at the levels of the optic chiasm-anterior commissure rostrally and the mammillary bodies caudally. 'The cortex bounded medially by the approximately sagittal plane of the lateral ventricle (to exclude cingulate cortex) and laterally by the rhinal fissure was taken. Where indicated, brain regions were weighed prior to extraction. Eyes were hemisected at the equator and retinas were dissected from the pigment epithelium with a spatula.

'Tissue extraction was performed according to the method of Rorstad et al. (1979) with modifications. Tissues were placed in tubes containing 10 to $20 \mathrm{vol}$ of ice cold $2 \mathrm{M}$ acetic acid and kept on dry ice until processed further. The tubes were placed in boiling water for $5 \mathrm{~min}$, the tissues were homogenized by sonication followed by freezing and thawing, and the resulting homogenate was centrifuged and decanted. The supernatant was lyophilized and the residue was stored at $-30^{\circ} \mathrm{C}$. On the day of assay, the residue was reconstituted in radioimnunoassay buffer $(0.10 \mathrm{M}$ sodium phosphate buffer, $\mathrm{pH} 7.2$, containing $0.05 \mathrm{M} \mathrm{NaCl}, 0.01 \mathrm{M}$ EDTA, $0.02 \%$ sodium azide, and $0.1 \%$ bovine serum albumin) and centrifuged, and the supernatant was diluted appropriately. Mean recovery of synthetic somatostatin-14 added to brain tissue homogenates was greater than $85 \%$ in each of four experiments.

Somatostatin radioimmunoassay. SLI was determined by a specific double antibody radioimmunoassay (RIA) developed by Arnold et al. (1982) using a primary antiserum raised in a rabbit to synthetic somatostatin-14 coupled to thyroglobulin. [ $\mathrm{Tyr}^{1}$ ]Somatostatin-14 was iodinated using the chloramine $\mathrm{T}$ method (Schonbrunn and Tashjian, 1978). The assay primarily recognizes residues 6 to 10 of somatostatin-14, the region of the molecule most important for biological activity in inhibiting growth hormone release from dispersed pituitary cells in culture (Vale el al., 1978), and has no significant crossreactivity with any of a series of peptide hormones tested. In tissue extracts, the assay recognizes at least four different forms of immunoreactive somatostatin as defined by gel permeation chromatography; somatostatin14 and somatostatin-28 are recognized on an equimolar basis. There is approximately $25 \%$ cross-reactivity with dihydrosomatostatin. CSH added to RIA tubes at concentrations of $0.04 \mathrm{M}$ and less does not interfere with the assay. The concentration of CSH present in the tissue extracts examined in this study is unknown, but, assuming uniform distribution of the drug in total body water, it is estimated to be less than $0.5 \mathrm{~mm}$ prior to dilution in the assay.

Protein assay. Aliquots of the crude tissue homogenates in acetic acid were added to an excess of $0.4 \mathrm{M}$ perchloric acid, the resulting precipitate was redissolved in $1 \mathrm{~N} \mathrm{NaOH}$, and protein was measured by a fluorometric procedure (Bohlen et al., 1973) using bovine serum albumin as a standard.

Gel permeation chromatography. Acetic acid extracts of hypothalami were added in a volume of $1 \mathrm{ml}$ to a 1.5 $\times 80 \mathrm{~cm}$ column of Bio-Gel P-30 (100 to $200 \mathrm{mesh}$ ) and eluted with $1 \mathrm{M}$ acetic acid under hydrostatic pressure. Two-milliliter fractions were collected, evaporated to dryness in a vacuum centrifuge (Savant, Hicksville, NY), redissolved in $1 \mathrm{ml}$ of RIA buffer, and assayed for SLI. Column recoveries of immunoreactivity of tissue extracts and of synthetic somatostatin-14 varied from 75 to $106 \%$.

Statistical analysis. One-way analysis of variance and Student's $t$ test (two tailed) were employed.

\section{Results}

Dose-response. The effects of different doses of CSH on the SLI concentration in the hypothalamus, retina, and parietal cortex are shown in Figure 1. A dose-dependent depletion of SLI occurred with doses of CSH ranging from 30 to $300 \mathrm{mg} / \mathrm{kg}$. The depletion appears to be maximal at a dose of $90 \mathrm{mg} / \mathrm{kg}$ of body weight, with 300 $\mathrm{mg} / \mathrm{kg}$ producing no further depression of SLI concentration. The maximum depletion in each region was approximately 50\%. The dose-response study was truncated at a dose of $300 \mathrm{mg} / \mathrm{kg}$, as larger doses made the animals ill. At $300 \mathrm{mg} / \mathrm{kg}$, the animals appear somewhat lethargic for several hours following the injections but continue eating and drinking, do not lose body weight, and have a normal duodenal mucosa by gross inspection. At a dose of $600 \mathrm{mg} / \mathrm{kg}$, all of the animals develop duodenal ulcers and $40 \%$ die from perforation of the ulcer and sepsis within $24 \mathrm{hr} ; 100 \%$ die within $48 \mathrm{hr}$. At doses of $1200 \mathrm{mg} /$ $\mathrm{kg}$, the rats uniformly develop generalized seizures and die within 2 to $4 \mathrm{hr}$ of administration of the drug.

As shown in the regional study below (Table I), surviving animals examined $24 \mathrm{hr}$ after a dose of $600 \mathrm{mg} / \mathrm{kg}$ of cysteamine $\mathrm{HCl}$, consistently have a greater depletion of 
SLI from the CNS than do animals given only $300 \mathrm{mg} /$ $\mathrm{kg}$. Therefore, it may not be concluded that, under all circumstances, a maximum effect is seen after a single systemic dose of $300 \mathrm{mg} / \mathrm{kg}$. Other routes of administration, such as intracerebral or intraventricular administration, and other dosage schedules, such as multiple dose regimens, were not explored in this study.

Regional distribution. The degree of depletion of SLI, expressed as nanograms per mg, wet weight, of tissue, in various regions of the CNS was examined $24 \mathrm{hr}$ after a single dose of cysteamine $\mathrm{HCl}, 300 \mathrm{mg} / \mathrm{kg}$, s.c. The results of one experiment are shown in Table I. The effect of CSH is seen to be generalized, occurring in all brain regions examined as well as in the retina and cervical spinal cord. The mean depletion of SLI caused by a dose of $300 \mathrm{mg} / \mathrm{kg}$ was somewhat variable, ranging from $39 \%$ in the cerebral cortex to $65 \%$ in the cervical spinal cord.

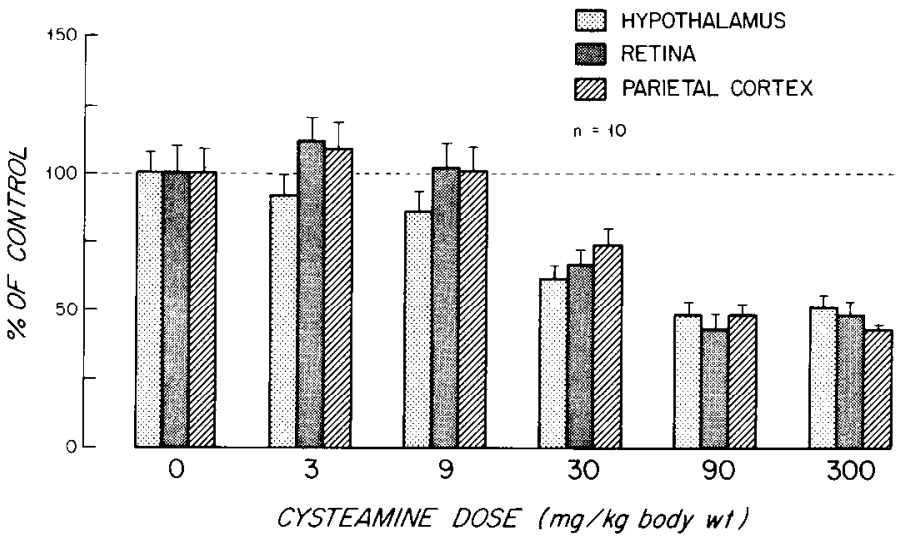

Figure 1. Dose-response. Rats ( $n=10$ in each group) were given either $0.9 \mathrm{M} \mathrm{NaCl}(0$ dose) or the indicated doses of $\mathrm{CSH}$ $\mathrm{HCl}$ as a single subcutaneous injection in a volume of $3 \mathrm{ml} / \mathrm{kg}$. Animals were killed $4 \mathrm{hr}$ later; retinas, hypothalami, and parietal cortex were dissected, extracted in acetic acid, and assayed for SII and protein. The mean concentrations of SLI in treated groups are expressed as a percentage of the mean control concentration. All mean values at doses of 30,90 , and $300 \mathrm{mg} /$ $\mathrm{kg}$ are significantly different than controls $(\rho \leq 0.01)$. The mean SLI concentrations of controls were: hypothalamus, $6.82 \mathrm{ng} / \mathrm{mg}$ of protein; retina, $0.63 \mathrm{ng} / \mathrm{mg}$ of protein; parietal cortex, 0.98 $\mathrm{ng} / \mathrm{mg}$ of protein.
This general pattern was confirmed in a repeat experiment (data not shown), with the cervical spinal cord being the most affected of the regions examined, the cerebral cortex the least, and other regions being intermediate in degree. The hippocampus was examined in a single experiment in which SLI was diminished $16 \pm 6 \%$ $24 \mathrm{hr}$ after $300 \mathrm{mg} / \mathrm{kg}$ of $\mathrm{CSH}$, but this difference was not statistically significant. As noted above, in both replicates of this experiment and in all regions examined, there was a greater degree of depletion of SLI in surviving animals receiving $600 \mathrm{mg} / \mathrm{kg}$ of $\mathrm{CSH}$ than in those receiving $300 \mathrm{mg} / \mathrm{kg}$. At the higher dose, however, there was a mortality of 3 of 7 animals in both replicates, and all surviving animals had perforated duodenal ulcers and were septic at the time of sacrifice.

Time course. Figure 2 demonstrates the time course of SLI depletion in the hypothalamus, retina, and parietal cortex following $\mathrm{CSH}, 300 \mathrm{mg} / \mathrm{kg}$, s.c. The depletion occurs within $4 \mathrm{hr}$ of drug injection in the regions examined and persists for at least $24 \mathrm{hr}$. Within 1 week, the parietal cortex has returned to normal concentrations of SLI, while the hypothalamus and retina have recovered toward normal but remain statistically lower than controls. A replication of this experiment (Fig. 3), examining more time points but with only 6 animals in each group, confirms these observations and shows that SLI depletion occurs as early as $2 \mathrm{hr}$ in the hypothalamus. In this second experiment, the mean concentration of SLI in the parietal cortex at $24 \mathrm{hr}$ was not significantly different from controls. In both of the time course experiments (Figs. 2 and 3), the hypothalamus SLI is depleted to a greater degree at $24 \mathrm{hr}$ than that in retina, and parietal cortex SLI is depleted less than that in retina, in partial confirmation of the regional study discussed above. At earlier times, the rank order of degree of depletion among the three regions differs from that at $24 \mathrm{hr}$. It may well be, therefore, that the variation among regions noted at $24 \mathrm{hr}$ is the result of differences in the time course of, rather than differences in susceptibility to, the effect of $\mathrm{CSH}$

Gel permeation chromatography. Elution profiles on a Bio-Gel P-30 column of pooled hypothalamic extracts from rats killed $4 \mathrm{hr}$ following either saline or $\mathrm{CSH}, 300$

TABI.F I

Regional distribution of SLI following systemic CSH administration

Rats received either $0.9 \mathrm{M} \mathrm{NaCl}, 3 \mathrm{ml} / \mathrm{kg}$, s.c., or $\mathrm{CSH} \mathrm{HCl}$ at the doses indicated. Twenty-four hours later, they were decapitated and brain regions and the cervical spinal cord were dissected, weighed, extracted, and assayed for SLI (see "Materials and Methods"). The mean SLI of all regions listed of rats receiving $\mathrm{CSH}, 300 \mathrm{mg} / \mathrm{kg}$, are significantly different than controls $(p \leq 0.05)$.

\begin{tabular}{|c|c|c|c|c|c|}
\hline \multirow{3}{*}{ Region } & \multirow{3}{*}{$\begin{array}{c}\mathrm{NaCl}(n=7) \\
\text { ng SLI/mg }\end{array}$} & \multicolumn{4}{|c|}{ CSH } \\
\hline & & \multicolumn{2}{|c|}{$300 \mathrm{mg} / \mathrm{kg}(n=6)$} & \multicolumn{2}{|c|}{$600 \mathrm{mg} / \mathrm{kg}(n=4)$} \\
\hline & & $\mathrm{ng} \mathrm{SLI} / \mathrm{mg}$ & $\%$ Depletion & ng SLI/mg & \% Depletion \\
\hline Cerebral cortex & $0.25 \pm 0.02$ & $0.15 \pm 0.01$ & 38 & $0.11 \pm 0.01$ & 54 \\
\hline Striatum & $0.10 \pm 0.01$ & $0.089 \pm 0.006$ & 52 & $0.70 \pm 0.01$ & 62 \\
\hline Midbrain-thalamus & $0.22 \pm 0.01$ & $0.082 \pm 0.003$ & 63 & $0.055 \pm 0.003$ & 75 \\
\hline Cervical spinal cord & $0.34 \pm 0.04$ & $0.12 \pm 0.03$ & 65 & $0.084 \pm 0.003$ & 75 \\
\hline Retina" $^{\prime \prime}$ & $0.31 \pm 0.02$ & $0.16 \pm 0.01$ & 48 & $0.11 \pm 0.02$ & 64 \\
\hline
\end{tabular}

"Retinas were treated as were other regions but were not weighed prior to extraction. Concentrations are expressed as nanograms of SLI per retina. 


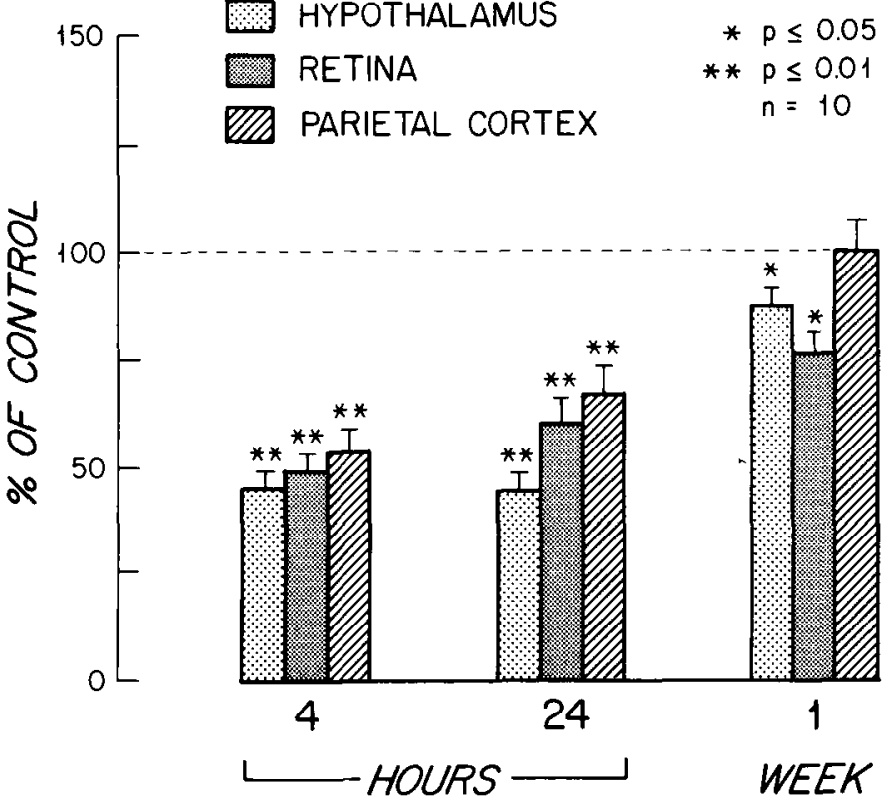

Figure 2. Time course. A total of 60 rats received either 0.9 $\mathrm{M} \mathrm{NaCl}$ or CSH HCl, $300 \mathrm{mg} / \mathrm{kg}$, s.c., in a volume of $3 \mathrm{ml} / \mathrm{kg}$ at time 0 . At the indicated intervals after injection, 10 control and 10 treated animals were killed and their retinas, hypothalami, and parietal cortex were dissected, extracted, and assayed for SLI and protein. Control groups were found not to differ significantly by one-way analysis of variance; therefore, the results of all control groups were combined and the mean concentrations of SLI per mg of protein for treated groups are shown as percentages of control means. Statistical significance was assessed by a two-tailed $t$ test. The mean SLI concentrations of controls were: hypothalamus, $8.24 \mathrm{ng} / \mathrm{mg}$ of protein; retina, 0.84 $\mathrm{ng} / \mathrm{mg}$ of protein; parietal cortex, $1.60 \mathrm{ng} / \mathrm{mg}$ of protein.

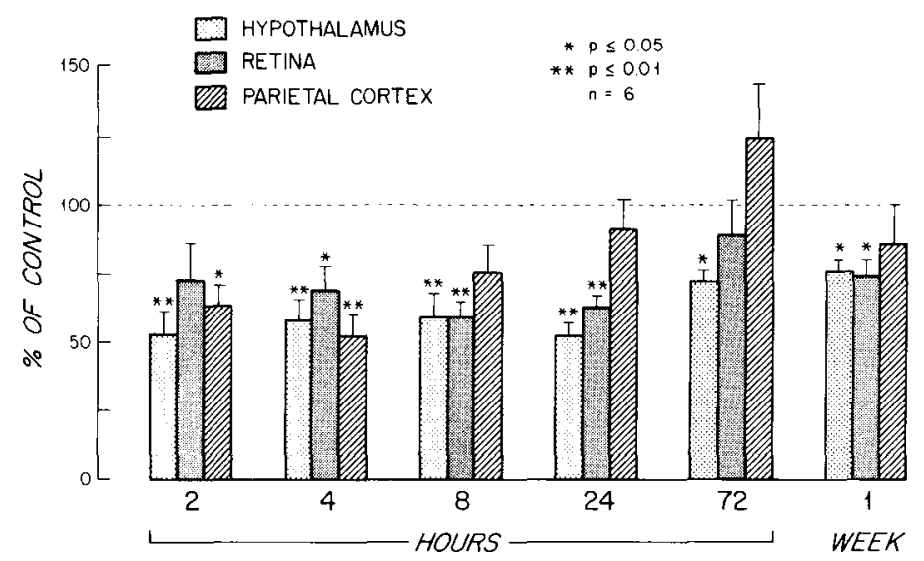

Figure 3. Time course. The experimental design and data analysis were identical to that of Figure 2 except that 72 rats were divided into groups of 6 each. The mean SLI concentrations of controls were: hypothalamus, $9.06 \mathrm{ng} / \mathrm{mg}$ of protein; retina, $0.46 \mathrm{ng} / \mathrm{mg}$ of protein; parietal cortex, $1.97 \mathrm{ng} / \mathrm{mg}$ of protein.

$\mathrm{mg} / \mathrm{kg}$, s.c., are shown in Figure 4. Control hypothalami, under these chromatographic conditions, reproducibly demonstrate five peaks of SLI. The most abundant and most slowly migrating material co-chromatographs with somatostatin-14 (peak $V$ ); the next most abundant material co-elutes with somatostatin-28 (peak IV). These two peaks together comprise about $90 \%$ of the total tissue immunoreactivity. The remainder of the immunoreactive material migrates on the column as three peaks: one which migrates near dextran blue (peak $I$ ), one migrating approximately with cytochrome $c\left(M_{\mathrm{r}}=12,300\right.$; peak $\left.I I\right)$, and one peak intermediate between cytochrome $c$ and somatostatin-28 (peak III). The extracts from CSHtreated rats at all three time points demonstrate qualitatively the same elution profile as control animals, with no alteration in elution volumes of peak tubes nor extraneous peaks. However, the heights of all five peaks are quantitatively reduced in $\mathrm{CSH}$-treated animals examined 4 and $24 \mathrm{hr}$ following $\mathrm{CSH}$ administration when compared to controls. Table II shows the total content of immunoreactivity recovered in each peak as well as the percentage of recovered immunoreactivity represented by each peak. The majority of the reduction in SLI concentration induced by $\mathrm{CSH}$ is accounted for by reductions in peaks $I V$ and $V$, the material which co-elutes with somatostatin-28 and somatostatin-14, respectively.
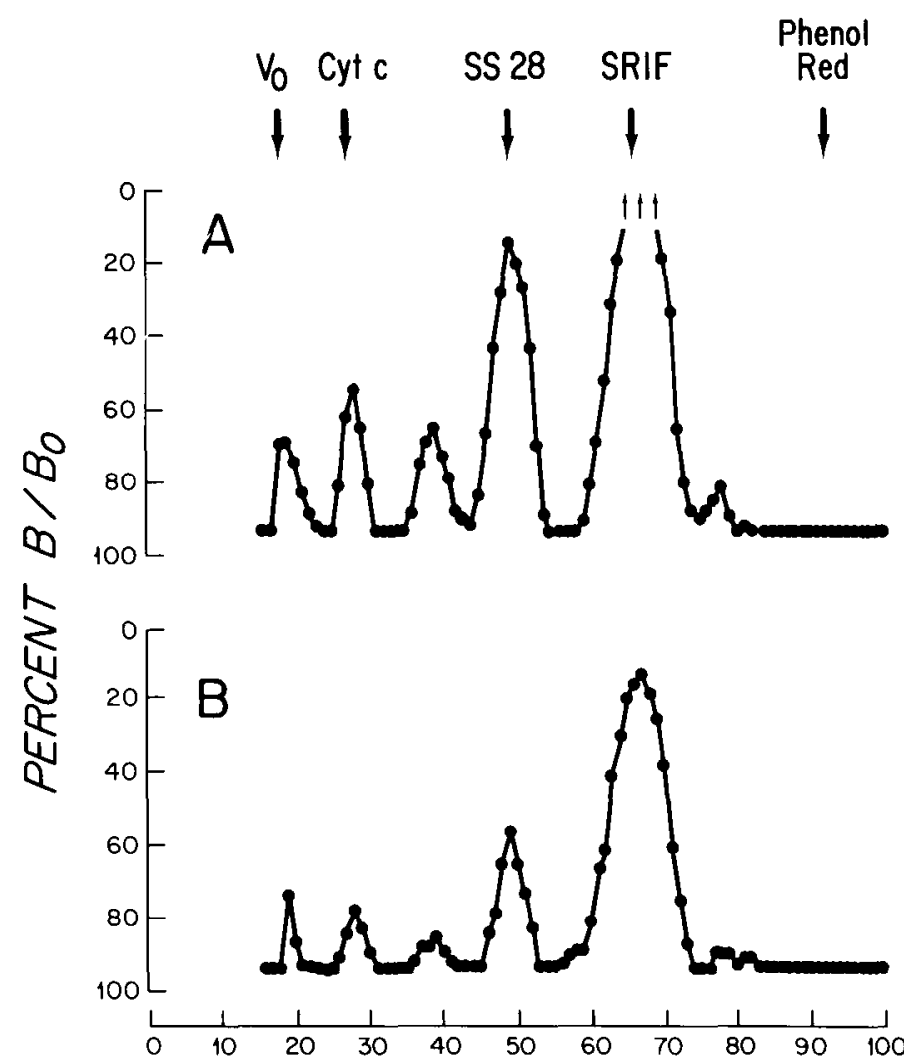

\section{FRACTION NUMBER}

Figure 4. Gel permeation chromatography. Pooled aliquots of acetic acid extracts of the hypothalami of the animals used in the experiment of Figure 3 were layered in a volume of $1 \mathrm{ml}$ onto a $1.5 \times 80 \mathrm{~cm}$ column of Bio-Gel P-30 eluted with $1 \mathrm{M}$ acetic acid. Two-milliliter fractions were collected, evaporated to dryness, redissolved in $1 \mathrm{ml}$ of RIA buffer, and assayed for SLI. $V_{0}$ is the elution volume of dextran blue, $c y t c$ that of horse heart cytochrome $c\left(M_{\mathrm{r}}=12,300\right)$, SS 28 that of somatostatin28 , and $S R I F$ that of somatostatin-14. Results from control $(A)$ and CSH-treated animals $(B)$ killed $4 \mathrm{hr}$ following drug administration are shown. $B / B_{0}$ is the ratio of counts of labeled hormone bound in the presence of the column fraction divided by counts bound in the absence of added hormone. 
TABLE II

Proportion of molecular forms of SLI

Aliquots of acetic acid extracts, prior to lyophilization, of hypothalami of each group of animals of the experiment of Figure 2 were pooled and chromatographed on a Bio-Gel P-30 column. After locating each peak of SLI by RIA, aliquots of fractions comprising each peak were combined and assayed for SLI. The values given are nanograms of SLI in each peak, with the percentages of the total recovered immunoreactivity represented by each peak given in parentheses.

\begin{tabular}{|c|c|c|c|c|c|}
\hline & \multicolumn{5}{|c|}{ Peak } \\
\hline & $\mathbf{I}$ & II & III & IV & V \\
\hline $\begin{array}{c}\text { Controls } \\
\text { Mean }\end{array}$ & $\begin{array}{r}2.02 \\
(5.0)\end{array}$ & $\begin{array}{r}1.00 \\
(2.5)\end{array}$ & $\begin{array}{r}0.68 \\
(1.7)\end{array}$ & $\begin{array}{c}7.8 \\
(19.0)\end{array}$ & $\begin{array}{c}29.2 \\
(71.8)\end{array}$ \\
\hline Range & $\begin{array}{l}1.81-2.26 \\
(4.2-5.5)\end{array}$ & $\begin{array}{c}0.81-1.19 \\
(1.9-2.8)\end{array}$ & $\begin{array}{c}0.64-0.74 \\
(1.5-2.0)\end{array}$ & $\begin{array}{c}7.3-8.1 \\
(17.1-22.2)\end{array}$ & $\begin{array}{c}24.4-32.2 \\
(67.4-75.3)\end{array}$ \\
\hline $24 \mathrm{hr}$ & $\begin{array}{r}1.57 \\
(8.9)\end{array}$ & $\begin{array}{r}0.56 \\
(3.2)\end{array}$ & $\begin{array}{c}0.52 \\
(3.0)\end{array}$ & $\begin{array}{r}2.33 \\
(13.3)\end{array}$ & $\begin{array}{c}12.5 \\
(71.6)\end{array}$ \\
\hline 1 week & $\begin{array}{r}2.66 \\
(7.3) \\
\end{array}$ & $\begin{array}{c}1.18 \\
(3.2)\end{array}$ & $\begin{array}{r}0.64 \\
(1.7)\end{array}$ & $\begin{array}{r}6.13 \\
(16.7) \\
\end{array}$ & $\begin{array}{c}26.0 \\
(71.0)\end{array}$ \\
\hline
\end{tabular}

\section{Discussion}

This study confirms the observation of Szabo and Reichlin (1981) that SLI in the hypothalamus is diminished by the systemic administration of cysteamine. We have extended their observations in demonstrating the effect of CSH to be generalized throughout the CNS, where it is of rapid onset and largely reversible. There is a marked degree of variation in depletion of SLI among brain regions when examined at a given time interval following drug administration. Our data indicate that this variation is due, at least in part, to differences in the time course of action of $\mathrm{CSH}$, as the maximum degree of depletion of SLI obtained is similar in all regions. Whether the partial depletion of SLI observed is a consequence of CSH acting on a restricted pool of SLI or whether greater degrees of depletion may be obtained with other routes or schedules of administration has not been resolved.

The mechanism of action of CSH is of great interest in regard to both the pharmacology of $\mathrm{CSH}$ and its potential use as a tool to investigate the basic biochemistry of somatostatin. CSH has a large number of documented biochemical actions, several of which could be relevant to its effect on tissue concentrations of SLI. The agent could act either by inhibiting the synthesis of somatostatin-14 and its precursors or by promoting its degradation or loss of immunoreactivity. We suspect that CSH is not acting as a general inhibitor of peptide synthesis, as hypothalamic concentrations of gonadotropin-releasing hormone are unaffected by the agent (Badger et al., 1982). CSH has been shown, however, to inhibit mRNA synthesis, as measured by the incorporation of $\left[{ }^{3} \mathrm{H}\right]$ uridine into acid-insoluble material in Escherichia coli and in mouse bone marrow cells (Naslund and Ehrenberg, 1978; Forsberg et al., 1978), an action that clearly could lead to a nonspecific inhibition of peptide synthesis. Moreover, in humans with cystinosis, $\mathrm{CSH}$, at doses of $90 \mathrm{mg} / \mathrm{kg} /$ day, reduces plasma cystine concentration; if this were to occur in normal animals, a specific inhibition of the synthesis of cysteine-containing peptides might result. If $\mathrm{CSH}$ acts by inhibition of somatostatin synthesis, one might not expect the onset of the effect to be as rapid as il is, and higher molecular weight forms of immunoreactive somatostatin, which are presumed to be, at least in part, precursors of the tetradecapeptide, would be depleted predominantly at early time points. The gel permeation chromatography data obtained in this study suggest that it is the lower molecular weight forms which are affected preferentially.

$\mathrm{CSH}$ is thought to act in depleting cystine from cystinotic fibroblasts by forming a mixed disulfide with cysteine (Thoene et al., 1976). Somatostatin-14 depends on an intact disulfide bridge between cysteine residues 3 and 14 of the tetradecapeptide for both its biological (Rivier et al., 1975) and, in our assay, immunological activity. $\mathrm{CSH}$ present in the RIA at concentrations of $0.04 \mathrm{M}$ and less does not affect the immunoreactivity of either synthetic somatostatin-14 or brain extracts. Nevertheless, if $\mathrm{CSH}$ reacts directly with intracellular somatostatin to form a mixed disulfide or acts indirectly to disrupt the formation of the appropriate disulfide bridge during peptide processing, then SLI would be expected to be reduced in the tissue extracts. Measurements of tissue concentrations of other cystine-containing peptides, such as vasopressin and insulin, after $\mathrm{CSH}$ administration would be of interest.

Sulfur-containing compounds, such as cysteine, are known to be neurotoxic, presumably through an excitotoxic mechanism (Olney et al., 1971). It is possible that $\mathrm{CSH}$ or a metabolite excites a cell surface receptor to induce the release and subsequent degradation of somatostatin. Szabo and Reichlin (1981) found no rise in plasma SLI following the oral administration of CSH, an observation which argues against this hypothesis. More direct experiments, examining the effect of $\mathrm{CSH}$ on spontaneous and depolarization-induced release of somatostatin from neural tissue, are needed.

For CSH to be a useful research tool in blocking the actions of endogenous somatostatin in the CNS, there 
are many questions still to be answered. It is not known if $\mathrm{CSH}$ results in the death of somatostatin-containing cells, with subsequent reduction in peptide concentration, or whether the effect is exerted directly on the peptide without neuronal destruction. This latter possibility is suggested by the reversibility of the peptide depletion. The specificity of the effect, particularly with respect to other cysteine-containing peptides, has not been established. Furthermore, it has not been shown that the depletion of SLI obtained following a single systemic dose, on the order of $50 \%$, is of physiological significance. It is possible that a "readily releasable" pool of SLI is affected primarily by $\mathrm{CSH}$, in which case, its depletion may have dramatic physiologic consequences. Studies of the effect of CSH administration on hypothalamic-pituitary growth hormone regulation would be of obvious interest.

In normal, as well as in CSH-treated rats, we find five peaks of SLI by gel permeation chromatography. There are many published studies of the chromatographic characteristics of SLI extracted from rat brain (for example, Rorstad et al., 1979; Zingg and Patel, 1979; Lauber et al., 1979; Trent and Weir, 1981). All studies, including the present one, agree in finding the most abundant form of SLI in brain to co-elute with synthetic somatostatin-14 and the next most abundant to chromatograph with material with a molecular weight of 3,000 to 4,000 . A third and smaller peak elutes at approximately the position of cytochrome $c\left(M_{\mathrm{r}}=12,300\right)$, the material that we are terming peak II. We also find two additional peaks, one near the void volume (peak I) and one intermediate between cytochrome $c$ and somatostatin-28 (peak III). Dilution curves of the peak tube of peak I were not consistently parallel to that of synthetic somatostatin-14 (data not shown) so that this material may not be immunologically identical to somatostatin-14; alternatively, there may be some material in the peak which interferes with the radioimmunoassay. On the other hand, dilution curves of the material in peak III, as well as the remaining three peaks, does parallel that of synthetic somatostatin14. Moreover, the same elution profile is obtained when fractions are assayed using another antibody, the same used by Rorstad et al. (1979). Therefore, the additional peaks that we find are not due to differences in assay method.

Of the published chromatographic studies, only that of Lauber et al. (1979) reports a peak of SLI extracted from mammalian brain corresponding to our peak III. These workers used extraction and chromatographic techniques different from ours. Mouse hypothalami were extracted in $0.1 \mathrm{M} \mathrm{HCl}$, containing $8 \mathrm{M}$ urea, $5 \mathrm{~mm}$ phenylmethylsulfonyl fluoride, and $130 \mathrm{units} / \mathrm{ml}$ of aprotinin. Using Sephadex G-25 columns eluted with $0.1 \mathrm{M}$ formate, containing $0.1 \%$ Triton $\mathrm{X}-100$ along with phenylmethylsulfonyl fluoride and aprotinin, four peaks of SLI were resolved, with apparent molecular weights of approximately $15,000,10,000,6,000$, and 1,500 , respectively. On the other hand, Trent and Weir (1981) used techniques virtually identical to those used in the present study, including tissue extraction in $2 \mathrm{M}$ acetic acid and chromatography on Bio-Gel P-30 but found only three peaks of SLI in extracts of rat brain. Therefore, the apparent discrepancy between our results and those of Trent and
Weir (1981) may be due to some obscure difference in extraction technique or to a difference in storage conditions of tissue extracts or column fractions. It is our experience that the higher molecular weight forms of SLI disappear after prolonged storage in a neutral buffer. Consequently, tissue extracts and column fractions were stored either in acid or in lyophilized form and redissolved in neutral buffer on the day of assay.

The results of this study add to the large body of literature concerning the biological actions of $\mathrm{CSH}$. We believe that the neuroendocrine effects of CSH deserve further study. Whether it will prove to be a specific and useful neurotoxin for the investigation of somatostatin physiology remains to be seen. However, the elucidation of its mechanism of action will certainly be of interest. Moreover, as CSH is subjected to additional clinical trials in a variety of human diseases, most notably cystinosis, the study of its neuroendocrine consequences in humans is imperative.

\section{References}

Arnold, M. A., S. M. Reppert, O. P. Rorstad, H. T. Keutmann, M. J. Perlow, and J. B. Martin (1982) Daily pattern of somatostatin in the cerebrospinal fluid of the rhesus monkey: Effect of environmental lighting. J. Neurosci., in press.

Bacq, Z. M. (1965) Chemical Protection Against Ionizing Radiation, Charles C Thomas, Springfield, IL.

Badger, T. M., S. M. Sagar, W. J. Millard, J. B. Martin, and P. Rosenblum (1982) Cysteamine reduces scrum gonadotropin concentrations in adult male rats. Life Sci. 30: 245-252.

Bohlen, P., S. Stein, W. Dairman, and S. Udenfriend (1973) Fluorometric assay of proteins in the nanogram range. Arch. Biochem. Biophys. 155: 213-220.

Burgus, R., N. Ling, M. Butcher, and R. Guillemin (1973) Primary structure of somatostatin, a peptide that inhibits the secretion of pituitary growth hormone. Proc. Natl. Acad. Sci. U. S. A. 70: $684-688$.

Forsberg, J., M. Harms-Ringdahl, and L. Ehrenberg (1978) Interaction of ascorbate with the radioprotective effect of mercaptoethylamin. An exploratory study in mice, whole animals and cell cultures. Int. J. Radiat. Biol. 34: 245-252.

Glowinski, J., and L. L. Iversen (1966) Regional studies of catecholamine metabolism in the rat brain. I. The disposition of $\left[{ }^{3} \mathrm{H}\right]$ norepinephrine, $\left[{ }^{3} \mathrm{H}\right]$ dopamine and $\left[{ }^{3} \mathrm{H}\right]$ DOPA in various regions of the brain. J. Neurochem. 13: 655-669.

Lauber, M., M. Camier, and P. Cohen (1979) Higher molecular weight forms of immunoreactive somatostatin in mouse hypothalamic extracts: Evidence of processing in vitro. Proc. Natl. Acad. Sci. U. S. A. 76: 6004-6008.

Naslund, M., and L. Ehrenberg (1978) Suppression of induced $\beta$-galactosidase synthesis by cysteamine and its reversion by $\gamma$-irradiation in the presence of ascorbate. Int. J. Radiat. Biol. 34: 411-415.

Olney, J. W., O. L. Ho, and V. Rhee (1971) Cytotoxic effects of acidic and sulphur containing amino acids on the infant mouse central nervous system. Exp. Brain Res. 14: 61-76.

Pradayrol, L., H. Jornvall, V. Mutt, and A. Ribet (1980) NTerminally extended somatostatin: The primary structure of somatostatin-28. FEBS Lett. 109: 55-58.

Prescott, L. F., J. Polk, G. R. Sutherland, I. J. Smith, and A. T. Proudfoot (1976) Cysteamine, methionine, and penicillamine in the treatment of paracetamol poisoning. Lancet 2: 109113.

Rivier, J., P. Brazeau, W. Vale, and R. Guillemin (1975) Somatostatin analogs. Relative importance of the disulfide bridge and of the ala-gly side chain for biological activity. J. Med. Chem. 18: 123-126. 
Rorstad, O. P., J. Epelbaum, P. Brazeau, and J. B. Martin (1979) Chromatographic and biological properties of immunoreactive somatostatin in hypothalamic and extrahypothalamic brain regions of the rat. Endocrinology 105: 10831092.

Sagar, S. M., D. Landry, T. M. Badger, W. J. Millard, M. A. Arnold, and J. B. Martin (1981) Depletion of somatostatinlike immunoreactivity from rat central nervous system by cysteamine. Neurology 31: 63.

Schonbrunn, A., and A. H. Tashjian (1978) Characterization of functional receptors for somatostatin in rat pituitary cells in culture. J. Biol. Chem. 253: 6473-6483.

Selye, H., and S. Szabo (1973) Experimental model for production of perforating duodenal ulcers by cysteamine in the rat. Nature 244: 458-459.

Szabo, S., and S. Reichlin (1981) Somatostatin in rat tissues is depleted by cysteamine administration. Endocrinology 109: 2255-2257.
Thoene, J. G., R. G. Oshima, J. C. Crawhall, D. L. Olson, and J. A. Schneider (1976) Cystinosis. Intracellular cystine depletion by aminothiols in vitro and in vivo. J. Clin. Invest. 58: 180-189.

Trent, D. F., and G. C. Weir (1981) Heterogeneity of somatostatin-like peptides in rat brain, pancreas, and gastrointestinal tract. Endocrinology 108: 2033-2038.

Vale, W., J. Rivier, N. Ling, and M. Brown (1978) Biologic and immunologic activities and applications of somatostatin analogs. Metabolism 27: 1391-1401.

Yudkoff, M., J. W. Foreman, and S. Segal (1981) Effects of cysteamine therapy in nephropathic cystinosis. N. Engl. J. Med. 304: 141-145.

Zingg, H. H., and Y. C. Patel (1979) Somatostatin precursors: Evidence for presence in and release from rat median eminence and neurohypophysis. Biochem. Biophys. Res. Commun. 90: 466-472. 